\title{
MAKALAH PENULISAN DAFTAR PUSTAKA DENGAN MENGGUNAKAN METODE HARVARD,VANCOUVER DAN APA
}

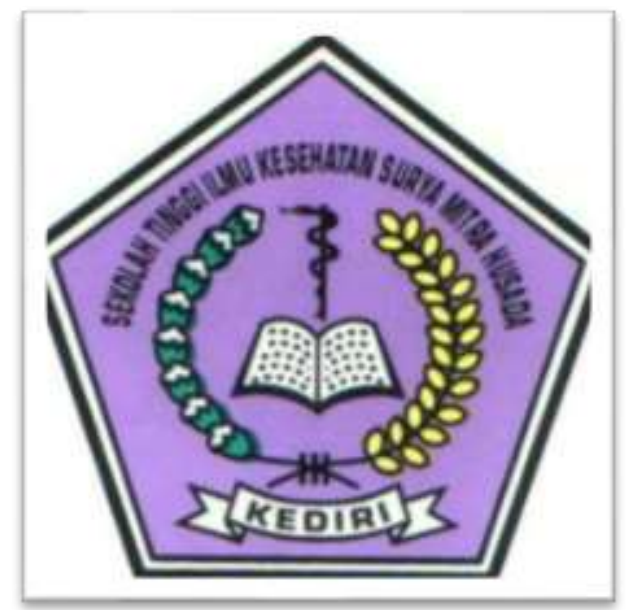

Disusun Oleh :

Nama : Moses Jakson Umbu Mawu

Nim : $1821 B 0035$

PROGRAM ILMU KESEHATAN MASYARAKAT

STIKES SURYA MITRA HUSADA KEDIRI

2018/2019 


\section{KATA PENGANTAR}

Puji syukur kami panjatkan kehadirat TUHAN YANG MAHA ESA karena atas berkat dan rahmatnya sehingga makalah yang berjudul "PENULISAN VANCOUVER,HARVARD,DAN APA “ ini dapat terselesaikan.

Tentunya penyusunan makalah ini masih terdapat banyak kekurangan serta masih jauh dari kata kesempurnaan. Untuk itu, kami mengharapkan kritik dan saran dari para pembaca yang sifatnya membangun.

Akhir kata kami mohon maaf apabila ada kesalahan dalam makalah ini. Semoga makalah ini dapat bermanfaat bagi kita semua.

PENULIS

KEDIRI,01 DESEMBER 2018 


\section{BAB I}

\section{PENDAHULUAN}

\section{A. Latar Belakang}

Daftar pustaka berisi informasi tentang sumber pustaka yang telah dirujuk dalam tubuh tulisan. Format perujukan pustaka mengikuti cara Harvard,cara Vancouver ataupun cara APA. Untuk setiap pustaka yang dirujuk dalam naskah harus muncul dalam daftar pustaka, begitu juga sebaliknya setiap pustaka yang muncul dalam daftar pustaka harus pernah dirujuk dalam tubuh tulisan.

Sistem Harvard menggunakan nama penulis dan tahun publikasi dengan urutan pemunculan berdasarkan nama penulis secara alfabetis. Publikasi dari penulis yang sama dan dalam tahun yang sama ditulis dengan cara menambahkan huruf a, b, atau c dan seterusnya tepat di belakang tahun publikasi (baik penulisan dalam daftar pustaka maupun sitasi dalam naskah tulisan). Alamat Internet ditulis menggunakan huruf italic. Terdapat banyak varian dari sistem Harvard yang digunakan dalam berbagai jurnal di dunia.

Sistem Vancouver menggunakan cara penomoran (pemberikan angka) yang berurutan untuk menunjukkan rujukan pustaka (sitasi). Dalam daftar pustaka, pemunculan sumber rujukan dilakukan secara berurut menggunakan nomor sesuai kemunculannya sebagai sitasi dalam naskah tulisan, sehingga memudahkan pembaca untuk menemukannya dibandingkan dengan cara pengurutan secara alfabetis menggunakan nama penulis seperti dalam sistem Harvard. Sistem ini beserta variasinya banyak digunakan di bidang kedokteran dan kesehatan.

"Smith (1983) menemukan bahwa tumbuhan pengikat $\mathrm{N}$ dapat diinfeksi oleh beberapa spesies Rhizobium yang berbeda". "Integrasi vertikal sistem rantai pasokan dapat menghemat total biaya distribusi antara 15\% sampai $25 \%$ (Smith,1949, Bond et al., 1955, Jones dan Green, 1963)." "Walaupun keberadaan Rhizobium normalnya mampu meningkatkan pertumbuhan kacangkacangan (Nguyen, 1987), namun telah didapat pula hasil yang berbeda bahkan berlawanan (Washington, 1999).”

\section{B. Rumusan Masalah}

Adapun rumusan masalah dalam makalah ini adalah :

1. Jelaskan penulisan daftar pustaka menggunakan metode Vancouver ?

2. Jelaskan penulisan daftar pustaka menggunakan metode Harvard ?

3. Jelaskan penulisan daftar pustaka mengunakan metode APA ? 


\section{BAB II \\ PEMBAHASAN}

\section{A. Metode Harvard}

Cara menulis daftar pustaka dengan metode Harvard dapat diikuti dengan langkah-langkah sebagai berikut :

1) Menuliskan nama penulis secara alfabetis

2) Mengurutkan tahun publikasi dengan urutan pemunculan berdasarkan nama penulis secara alfabetis

3) Jika terdapat publikasi dari penulis yang sama maka dituliskan berdasarkan urutan tahun publikasi tersebut

4) Jika publikasi tersebut berada dalam tahun yang sama (penulis sama), maka publikasi tersebut ditulis dengan cara menambahkan huruf a, b, c dan seterusnya yang berada tepat di belakang tahun publikasi.

5) Proses penulisan tersebut (poin 4) juga berlaku ketika menuliskan sitasi dalam naskah tulisan.

6) Nama tempat tulisan dari penulis tersebut dipublikasikan menggunakan huruf yang dicetak miring (italic)

7) Alamat Internet juga ditulis menggunakan huruf italic.

Contoh cara penulisan daftar pustka menggunakan Metode Harvard :

- Buller H, Hoggart K. 1994a. New drugs for acute respiratory distress syndrome. New England J Med 337(6): 435-439.

- Buller H, Hoggart K. 1994b. The social integration of British home owners into rench rural communities. J Rural Studies 10(2):197-210.

- Dower M. 1977. Planning aspects of second homes. di dalam Coppock JT (ed.), SecondHomes: Curse or Blessing? Oxford: Pergamon Pr. Hlm 210-237. 


\section{B. METODE VANCOUVER}

Adapun langkah-langkah yang dapat ditempuh dalam cara menulis daftar pustaka dengan metode Vancouver adalah sebagai berikut:

a) Menggunakan bullet angka

b) Angka tersebut menjadi rujukan dalam sitasi sebuah karya tulis yang dibuat

c) Nomor rujukan (referensi) yang ada di dalam karya tulis itu harus sama dengan urutan penulis yang ada dalam daftar pustaka

d) Tidak perlu mengurutkan tahun publikasi tulisan

e) Nama tidak perlu diurutkan berdasarkan alfabetis

Contoh cara menulis daftar pustaka dengan Metode Vancouver dapat dilihat pada contoh sebagai berikut:

1) Grinspoon L, Bakalar JB. Marijuana: the Forbidden Medicine. London: Yale Univ Pr; 1993.

2) Feinberg TE, Farah MJ, editors. Behavioural Neurology and 2. Neuropsychology. Ed ke2. New York: McGraw-Hill; 1997.

3) Grimes EW. A use of freeze-dried bone in Endodontic. J Endod 1994; 20:355-6.

4) Morse SS. Factors in the emergence of infectious disease. Emerg Infect Dis [serial online] 1995 Jan-Mar; 1(1):[24 screens].Available from URL: http://www/cdc/gov/ncidoc/EID/eid.htm. Accessed December 25, 1999.

\section{Metode APA (American Psychological Association)}

APA (American Psychological Association) style pada umumnya digunakan untuk mensitasi sumber-sumber referensi dalam bidang ilmu sosial. Pedoman sitasi ini menggunakan APA Style edisi revisi ke-6. APA Style memiliki dua bagian utama dalam penulisan sitasi:
a. Mengutip dalam teks (In-text citations)
b. Daftar pustaka / bibliografi (List of references) 
- In-Text Citations mengarahkan pembaca untuk menemukan informasi utuh sumber kutipan dalam daftar pustaka yang digunakan penulis.

- List of references mengarahkan pembaca untuk menemukan informasi daftar pustaka secara utuh tentang keseluruhan sumber informasi yang dirujuk penulis. List of references berada pada halaman terakhir dari karya tulis.

\section{Pengutipan di dalam Teks (in-text citations) Pedoman Dasar In Text Citations}

1. Sumber kutipan dapat ditulis diawal atau akhir kutipan.

2. Penempatan sumber kutipan (pada awal atau akhir kutipan) tidak boleh mengaburkan bagian yang dikutip.

3. Format in text citation menggunakan metode author-date, yaitu nama terakhir pengarang dan tahun terbit sumber yang dikutip muncul dalam teks, contoh (Retnawati, 2014), dan referensi harus muncul lengkap di daftar pustaka pada akhir tulisan.

4. Pencantuman halaman sumber kutipan setelah tahun bersifat wajib jika isi teks yang dikutip jelas letak halamannya. Tetapi jika kutipan gagasan/ide dari sumber referensi tidak langsung,tidak perlu menyebutkan nomor halaman dalam pengutipan teks 5. Kutipan singkat terdiri dari nama pengarang, tahun penerbitan, dan nomor halaman yang didahului tanda 'p.'

5. Semua sumber referensi yang dikutip dalam teks harus muncul dalam daftar pustaka

6. Kata pertama untuk proper noun (nama orang, tempat, dan nama benda secara spesifik), termasuk nama dan inisial pengarang selalu kapital, contoh M. Hatta, D. Jones

7. Semua kata dalam judul kapital dan dicetak miring The Closing of the American Mind (Catatan: dalam daftar pustaka hanya kata pertama yang dikapitalkan, contoh : The Closing of the American mind 
8. Semua judul karya jenis buku, dokumentasi, album, film dicetak miring, contoh : The Closing of the American Mind

9. Semua judul karya artikel diberi tanda kutip “...”,contoh : "Multimedia Narration: Constructing Possible Worlds"; "The One Where Chandler Can't Cry."

\section{Halaman Daftar Pustaka (References)}

1. Semua karya yang dikutip dalam penulisan karya tulis harus dimuat dalam daftar pustaka.

2. Daftar pustaka pada halaman terpisah dari uraian penulisan.

3. Ukuran margin seperti pada halaman penulisan.

4. Judul daftar pustaka berada di tengah dan tidak dicetak miring / tanda kutip.

5. Kapitalkan hanya huruf pertama pada kata pertama dan proper noun pada judul

6. Jarak antar karya (pustaka) dua spasi.

7. Inden pada baris kedua dengan jarak $1 / 2$ inch.

8. Daftar pustaka ditulis/diketik satu spasi, berurutan secara alfabetis tanpa nomor.

9. Jika literatur ditulis oleh satu orang, nama penulis ditulis nama belakangnya lebih dulu, kemudian diikuti singkatan (inisial) nama depan dan nama tengah, dilanjutkan penulisan tahun, judul dan identitas lain dari literatur/pustaka yang dirujuk.

10. Penulisan daftar pustaka tidak boleh menggunakan et al sebagai pedoman penulisannamapengarang. 


\section{CONTOHNYA :}

- Dua Atau Lebih Karya Dengan Pengarang Yang Sama

Daftar semua nama pengarang yang sama diikuti dengan tahun terbit dan diurutkan berdasarkan tahun terbit

Berndt, T. J. (1981).

Berndt, T. J. (1999).

- Dua Atau Lebih Karya Dengan Pengarang Yang Sama Dalam Tahun Yang Sama Tambahkan huruf setelah tahun terbit.

Berndt, T. J. (1981a). Age changes and changes over time in prosocial intentions and behavior between friends. Developmental Psychology, 17, 408-416.

Berndt, T. J. (1981b). Effects of friendship on prosocial intentions and behavior. Child Development, 52, 636-643. 


\section{BAB III \\ PENUTUP}

\section{A.KESIMPULAN}

Format perujukan pustaka mengikuti cara Harvard,cara Vancouver ataupun cara APA. Untuk setiap pustaka yang dirujuk dalam naskah harus muncul dalam daftar pustaka, begitu juga sebaliknya setiap pustaka yang muncul dalam daftar pustaka harus pernah dirujuk dalam tubuh tulisan.

Sistem Harvard menggunakan nama penulis dan tahun publikasi dengan urutan pemunculan berdasarkan nama penulis secara alfabetis. Sistem Vancouver menggunakan cara penomoran (pemberikan angka) yang berurutan untuk menunjukkan rujukan pustaka (sitasi). APA (American Psychological Association) style pada umumnya digunakan untuk mensitasi sumber-sumber referensi dalam bidang ilmu sosial. 


\section{DAFTAR PUSTAKA}

Buku : Eisen HN. Immunology: an introduction to molecular and cellular principles of the immune response. 5th ed. New York: Harper and Row, 1974:406

Sumber $\quad:$ http://okaindarmordayanti.wordpress.com/2013/04/08/impact-factor-icv-sistempenulisan-referensi/

http://mds-pro.tumblr.com/post/16109803836/format-penulisan-daftar-pustaka-vancouver http://repository.maranatha.edu/2522/8/Metlit\%20BAB\%20VII.pdf 